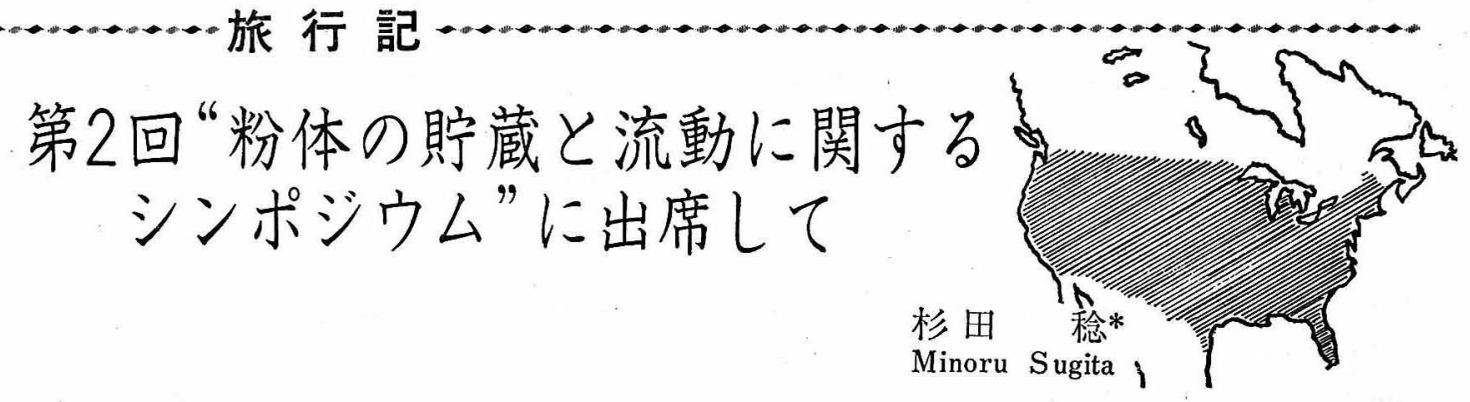

昨年の 9 月14日に，小雨降りしきる羽田空港を飛び立 ちまして, 約 4 週間程アメリカ各地を訪問する機会を得 ました。初めての海外旅行の興奮と不安を心に秘めて, サンフランシスコ空港に第一歩をしるしたのでした。

この旅行のまず第 1 の目的は，9月17日〜20日までの 4 日間にわたりまして, シカゴ市の中心街 North Michigan Ave. 飞面した Chicago-Sheraton Hotel 飞て開 催されました，「第2 回 粉体の町蔵と流動関するシン ポジウム」とでる訳せむしらか, “Second Symposium on Storage and Flow of Solids” 火出席することであ りました。

このシンポジウムは,アメリカの機械学会(A.S.M.E.), 土木学会 (A.S.C.E.), 化工学会 (A.I.Ch.E.), 鉱山学会 (A.I.M.E.) の 4 学会の共催で開催されました。主とし て A.S.M.E. が中心となって運営され, A.S.M.E. とA. I.Ch.E. の代表である，Dr. A.W. Jenike が本シンポジ ウムの委員長でありました。

すでに 4 年前, ボストンにて第 1 回のンンポジウムが 開催されて和ります。この時には北大の田中達夫教授ら が発表なさって特ります。そして,このレポートが A.S.

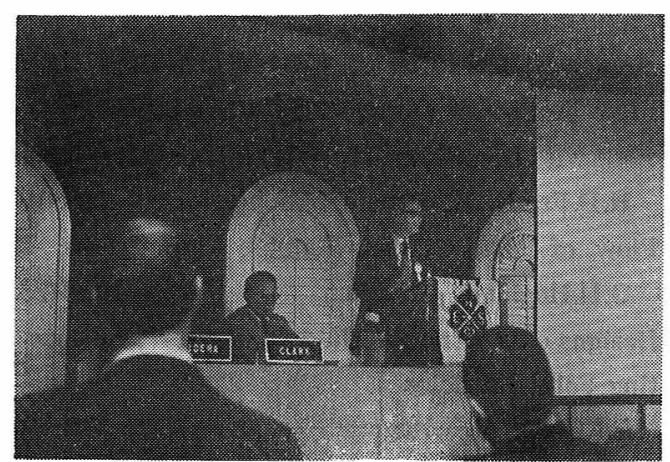

写真 1 Chairman の A.W. Jenike

昭和 48 年 3 月 13 日受理

* 清水建設 (株) 研究所 (T135 東京都汇東区越中島 3-4-17) T E L $03-643-4311$
M.E. Journal of Eng. for Industry, Vol. 91, May 1969，飞特集号として報告されていなす。

今回は, 主催国アメリカのほか, イギリス,ドイッ, 日本など 8 力国から，34編の論交が提出され，2会場で 100セションに分れて発表と討論が行なわれぬした。目 本からの発表論文は私の 1 編のみでして, 出席者も私と 現在アメリカに蛙られます。以前神興電気(株)の技師長 をして敊られました牧野氏の二人であったようです。

発表されました論文の内訳は，

\section{Bin Loads}

10編

2. Testing \& Analysis

7 編

3. Segregation \& Blending

3 編

4. Slurries 3 編

5. Feeders \& Flow Aids 11編

各論文の題目と著者名のリストを以下に示します。 Session I "BIN LOADS I"

Cause and prevention of Dust Explosions in Grain Elevators and Flour Mills

O.F.Theimer

$\mathrm{MH}-25$

Bin Loads II, Concepts

A.W.Jenike J.R. Johanson J.W.Carson MH-1 Flow Patterns and Wall Stresses in a Mass-Flow Bunker

P.M.Blair-Fish P.L.Bransby

$\mathrm{MH}-6$

Tests Dealing with Loading of Tie Bars in Silo Cells

\section{K.Pieper D.Kroll}

Session III “BIN LOADS II"

Pressures in Bunkers

\section{K.Clague H.Wright}

MH-31

Bin Loads III, Mass-Flow Bins

A.W. Jenike J.R. Johanson J.W.Carson MH-2

Flow and Pressures of Noncohesive Granular 
Materials in Funnel-Flow Bins

M.Sugita

MH-20

Wear-Resistant 'Materials for Steelworks Plant

Handling Coke and Sinter

H. Hocke

Session V "BIN LOADS III"

Lateral Pressures of Granular Materials in Silos

A.G.Homes

$\mathrm{MH}-30$

Bin Loads $\mathbb{N}$, Funnel-Flow Bins

A.W. Jenike J.R. Johanson J.W.Carson $\quad M H-3$

Session II "TESTING \& ANALYSIS I"

Stress-Velocity Relationships for Particulate Solids

J.Bridgwater

MH-21

Measurement of Powder Properties for Hopper Design

J.Schwedes

$\mathrm{MH}-8$

Application of Pseudo-Random Test Signals and Cross Correlation to the Identification of Bulk Handling Plant Dynamic Characteristics

A.W.Roberts W.H.Charlton

MH-15

Simulation by Computer-Graphics Display of

Solid flow in Storage Bins

W.T.Kao G.L.Downey Y.C.Pao

MH-22

Session $\mathbb{N}$ “TESTING \& ANALYSIS II"

Gravity Flow of Granular Materials : Analysis of Particle Transit Time

W.H.Charlton A.W.Roberts

MH-33

Gravity Flow Bin Design for Lunar Soil

W.G.Pariseau D.E.Nicholson

MH-24

An Evaluation of the Jenike Bunker Design Method

H. Wright

MH-7

Session VII

"SEGREGATION AND BLENDING"

Minimizing Segregation in Bunkers

K. Clague H.Wright

MH-16

A Geometric Study of In-Bin Blending

D.F.Bagster

MH-17

Preliminary Estimate of Mixing Effect of NonSegregating Materials in a Plug-Flow Bin

A.Wlodarski

$\mathrm{MH}-13$
Session VI "SLURRIES"

Slurry Flow in Pipes and Pumps

$$
\text { J.J.Vocadlo M.S.Sagoo }
$$

MH-10

Flow Behavior of Hematite Slurries

H. Y. Jennings

MH-12

Storage Aspects of Long Distance Slurry Pipelines

E.J.Wasp T.L.Thompson

MH-32

Session VII "FEEDERS \& FLOW AIDS I"

Aeration Apparatus Converts Bin from FunnelFlow to Mass-Flow Characteristics

R.B.Emery

MH-5

Bin Activators-Key to Practical Storage and Flow of Solids

E.A.Wahl

$\mathrm{MH}-29$

Improving the Flow of Lead-zinc Ore

P.Larson

MH-23

Georgia Kaolin Compny Solves Calciner Feed Problems

S.E.Valji C.L.Wilkinson

$\mathrm{MH}-26$

The Design of a Linear "Out-of-Phase" Vibratory Conveyor

R.E.Schofield

$\mathrm{MH}-4$

Session $\mathbb{X}$ “FEEDERS AND FLOW AIDS II" The Bougainville 975 TPH Feeder

W.A.Winkler

$\mathrm{MH}-14$

Feeding Calcine Dust with a Belt Feeder at Falconbridge

G.B.Reed J.R.Johanson

MH-11

Session X "FEEDERS AND FLOW AIDS III" Flow Studies of Dense-Phase Gas/Solid Suspensions with a Positive Expulsion Fluidization Tank

H.D.Fricke K.Berman M.Sobieniak MH-19 Flow of Particles in a Bistable Fluid Device

G.H.Hogland P.I.Chen

$\mathrm{MH}-28$

Designs of a Bistable Fluid Device for Transporting Solid Particles

P.I.Chen G.H.Hogland

MH-27

Automated Device for Dispensing Precise Amounts of Powder

J.M.Osborne H.R.Mcgraw C.F.Draut MH-18 
このほか, パネルディスカッションが, Bin Loads と Feeders の 2 部門にて行なわれました。

参加者は 1 会場だいたい 60 ～80人くらいでしたでしょ らか，かなり広い, East Room と: Tally Ho Room の 2 会場で平行して開催されました。

この会議のプログラムが日本出発のやっと 1 週間前に 届きまた，論文は会場に行ってから手に入るといった 具合で，会議の開催前までは一体どうなることかと心配 しましたが, 開催されてからは一応スムースな運営であ ったと思います。

ただ，会の運営費の方はかなり苦しいらしく，たとえ ばパーティなども, 飲物は各 1 ドルで買い求めて飲むよ らなわけで, 論文も 1 編につき 1 ドルで買い求めさせら れ，自分の Paper も 1 ドルで買わないと手に入らない 状態でした。 .

日本の学会の䨌团気と大きく異なっていた点は, 各国 のコンサルタント・エンジニアの活躍がたいへん注目さ れたことであります。研焭発表や会議の運営に挌いて も, 質議討論にても, 大学などの研究者以上の活発な活 躍をしていました。彼らは事務所を持って, 設計業務や その他各種のコンサルタントをしておりまして, この種 の会議を彼らの絶好の仕事場として, 昼食や夕食時なら びにパーティなどを利用しているよらでした。

発表の日は, 朝 7 時30分から, 癹表者, 座長, パネリ ストなどの打合せが朝食を取りながら行なわれました。 そこで発表者同志の紹介や，発表時間，スライド使用な ぞの発表方法などの打合せ, 発表者の紹介書の確認が行 なわれました。そして，9時になりますとそのまま全員 会場に行きまして発表が行なわれるのです。私の場合, どうした手違いか，日本から送って拈いた自己紹介文が 届いていませんで, その場で書かされまして, 朝食を落 着いて取るどころではめりませんでした。

研究発表にはスライド, 黒板, オーバーヘッドプロジ エクターとが用意されて特り，それぞれを使い分けて行 なわれました。

ここで, 私が主として聞いてまいりましたのが, “Bin Loads” 関係ですので, このセションでの三三の論文に ついて述べてみたいと思います。

このセションでは, 本会議の委員長と副委員長を勤め た, Dr. Jenike と Dr. Johanson とで作っている Jenike \& Johanson Inc. からの論文に触れないわけにはいきま せん。“Bin Loads II. III. N.”と 3 編の論文が発表さ れました。まず, Dr. Jenike が概論を述べ, 私の親友
であります，Dr. Carson が “Mass-Flow Bins” につい て, 最後に Dr. Johanson が “Funnel-Flow Bins” に ついて発表しました。この一連の発表は, Proc. A.S.C. E., Apr. 1968 ST. 4 に発表した “Bin Loads”のシリ ーズものとして, さらに研究を進めたものとして提出さ れたものです。

Initial Pressure (投入, 静置時の圧力) は, 広く用 いられている Janssen 值で十分であるが，排出時の Flow Pressureは, 歪エネルギー理論から導かれた圧力 包絡線内に括さまる。この関係を, 砂を用いたモデルビ ンによる圧力測定結果を示して論じていました。

Jenike チームは, Dr. Jenike を先頭に, 発表, 質問, 討議, 運営にと縱横の活躍をして会議をもりあげて扣り ました。

イギリス,ケンブリッジ大学の Dr. Bransby らは, 断面が $150 \times 150 \mathrm{~mm}$, 高さ $450 \mathrm{~mm}$ のモデルビンに, $60^{\circ} \mathrm{C}$ と $70^{\circ} \mathrm{C}$ の角度を持つホッパーを用い, 材料に砂を用いて 排出させた時の流動粉体中の密度の違いを，X線撮映に より研究し, その壁面に取りつけた Load Cellにより粉 体圧を測定した結果について発表して和りました。材料 の砂の中に同径の鋼球を配して流れのパターンや歪量な ぞを測定したところ, 密度の少ない部分がホッパーの上 端からアーチ状に形成され，この部分に高いWall Pressure が測定されたと興味ある発表を行なったのでした。 この発表に先だったパーティで, 初対面の私にわざわざ 挨拶に来られ，私のいら“崩壊面”之同じ現象がイギリ スでも観測されたと自分の撮映したX線写真を示して話 してくれまして，今後の情報の交換を約束してきたしだ いです。

西ドイッから参加された，有名なサイロ研究家，Dr. O. F. Theimer は粉じん爆発の防止について, 個々の事 故例を示しながら発表されました。彼は数少ない夫人同 伴者でして, 私に, 日本での事故例を送ってほしいと依 頼してきました。

そのほか, かなり興味ある内容の発表がなされて扣り ましたが紙面の都合上省略します。な䅂，先のリストの 論文はすべて私の手元にありますので，興味があり御希 望の方は御連絡下さい。

この旅行の第 2 の目的は, 先のシンポジウムに先だち まして, 同じシカゴで開かれましたアメリカコンクリー ト学会 (A.C.I.) の第313委員会に出席することでした。 この委員会は「コンクリート製サイロとビンの設計と施 工規準」を検討している委員会です。この委員会より， 日本からも委員を送るよらに日本コンクリート会議に要 
請がありまして，たまたま私がその推薦を得まして ACI の委員会の委員に加えさせていただいたしだいです。 会議は朝 9 時から夜中の12時まで, 昼と夜の食事を取 った 3 時間程を休憩しただけでの, ぶっつづけの討議で した。初めての海外旅行であり, まだ時差の影響の抜け なかった私にとりましては，たいへんきつい一日でし た。また，彼らのタフネスぶりを眼のあたりにした思い でした。

この会議に招きましては, すでと1965年, AC I 学会 誌にて発表された「コンクリート製サイロの設計扔よび 施工規準」の改訂と補足の作業を行なって和りました。

この委員会の下部組織である 6 つの小委員会から提出 された素案に，一つ一つ検討が加兄られていきました。 日本に怙けるサイロ設計と施工の現状について, ダブル 配筋での最小壁厚はいくらにしているかとか, 粉体圧の 算定式は何を用いているかなど，いろいろと意見を求め られました。

アメリカでの規準は，世界各国の規準として用いられ るといら, アメリカ人らしい自負心があり，できるだけ 各国の現状をらま光て規準を提案したいと，本委員会の
Safarian 委員長は抱負を述べて扬りました。乞のため か, 日本からの私の涂か, ドイッの Theimer 氏, フラ ンスからも委員が参加して沏りました。

まだ，設計規準を持たない日本に括いてはたいいん参 考になる点が多く，資料として配布された規準案など， 今後大いに検討し参考に生かしてゆきたいと考えていま す。

シカゴからイリノイ州の南部にあるアーバナ市のイリ ノイ大学を訪問に行く途中, たまたま知人の車でInterstate 57 号線をドライブする機会がありました。ここの 沿道は有名な穀倉地帯で, 両側一面かぎりなくメイッ゙畑 と大豆畑がつづいて挌りまして, 所々の農家には, 大き なコンクリート製や鉄板製の穀物サイロが見られまし た。たいていの農家は一軒に $2 \sim 3$ 個の家畜用サイロを 持って招り，大きな日本の製粉工場にあるような豰物サ イロと並んで対照的でありました。

それだけアメリカではより身近な間題として，粉体圧 とか貯槽の設計などが真剣に考えられているのだと思い あたったのでした。

$$
\text { [ニュース }
$$

\section{西ドイツにおける最近の大型穀物サイロの崩壊例}

西ドイッの著名な粉体貯槽研究家であり, 現在コンサ ルタントェンジニアとして世界的に活躍して扣られる O. F. Theimer 博士が最近知らせて下さった, 西ドイッ での大型穀物サイロの崩壊例を紹介しよう。

昨年の11月 8 日, 北ドイッの Weser 河のほとりに市 る Brake 市の J. Müller Co. で鉄筋コンクリート製大 型独立サイロの一つが完全に崩壊した。このサイロは昨 年完成したばかりの五つの大型円形独立サイロの一つで あった。サイロの規模は直径が $11.50 \mathrm{~m}$, 高さ $75.50 \mathrm{~m}$, ホッパー底部に二つの排出口があり, 排出口よりホッパ 一上端まで約 $6.0 \mathrm{~m}$ の高さである。ホッパー上端部に排 出時アーチ防止用の大きな insert beam (高さ $5.20 \mathrm{~m}$, 幅 $2.30 \mathrm{~m}$ ）が設置されている。貯槽壁厚は $22.0 \mathrm{~cm}$ で上 部まで同一厚である。特とらくスライディングフォーム 工法で施されたものと思われる。地震国の日本ではちょ っと想像できない程の大きなサイロである。

これらのサイロは西ドイッ基準 DIN 1055, B1. 6 飞 もとづいて設計され，サイロ下部での設計側圧值は 7.0 $\mathrm{t} / \mathrm{m}^{2}$ であるという。

・崩壊時にはカナダから輸入されたメイヅ（トウモロコ
シ) 嵩比重 $0.74 \mathrm{t} / \mathrm{m}^{3}$ が約 $4500 \mathrm{t}$ 程が貯蔵されていた。 崩壊した前日，貯蔵されていたメイヅが貯槽内で約 45 ${ }^{\circ} \mathrm{C}$ 温度上昇したので，メイヅを空気にふれさせて冷却 するためサイロより排出をはじめたところ, サイロの下 部 $1 / 3$ の部分にクラックが発生した。最初クラック幅は 8 〜 10mm 程であった。そして翌日の朝, 11月 8 日朝, に 貯槽の下部が崩壊し，その上部は倒壊した。貯蔵されて いた4500 t のメイジが崩壞したサイロとともにあたり一 面に散乱した。

幸いにも一人の死者もけが人も出なかったが，物質的 損害とトウモロコシの損失と再建の費用とで約 100 万ド ルの損害であった。

この崩壊時の状況から考えて, 排出開始時にホッパー との接合部近傍の垂直壁に作用した dynamic over pressure の発生がその主たる原因と考えられる。また流動 調整用の水平梁が大きな影響を与えているものと思う。

現在詳細な検討が Theimer 博士のもとで行なわれて いるもようなので，この事故をるとに䝪槽粉体圧の研究 がまたさらに一段と進展されるものと期待される。

(杉田) 